\title{
A description of the nymph of Anacroneuria ofaye Froehlich (Plecoptera: Perlidae) and a apparatus for rearing Neotropical stonefly species
}

\author{
MARCOS CARNEIRO NOVAES ${ }^{1,2}$, PITÁGORAS DA CONCEIÇÃO BISPO ${ }^{2} \&$ JANET HIGUTI $^{3}$ \\ ${ }^{1}$ Departmento de Biologia, USP, Ribeirão Preto, Brazil \\ E-mail address: marcosdenovaes@hotmail.com \\ ${ }^{2}$ Departmento de Ciências Biológicas, UNESP, Assis, Brazil \\ E-mail address: pcbispo@gmail.com \\ ${ }^{3}$ NUPELIA, UEM, Maringá, Brazil \\ E-mail address: janethiguti@gmail.com \\ Contact Address: \\ Laboratório de Biologia Aquática - UNESP \\ Avenida Dom Antônio, 2100 \\ Parque Universitário \\ Assis - SP \\ Brazil \\ C.E.P.: 19806-900 \\ E-mail address: pcbispo@gmail.com
}

\begin{abstract}
The Neotropical genus Anacroneuria (Perlidae) is represented by more than 300 species. Among the Brazilian Anacroneuria, only the nymphs of two species have been described. In this paper, we described the nymph of $A$. ofaye Froehlich and an apparatus for rearing this genus. This is the first record of A. ofaye from Paraná State, Brazil.
\end{abstract}

Keywords: Plecoptera, Anacroneuria, nymph, rearing apparatus, Brazil

\section{Resumo}

O gênero neotropical Anacroneuria (Perlidae) é representado por mais de 300 espécies. Entre os Anacroneuria brasileiros, apenas as ninfas de duas espécies foram descritas. Neste trabalho, descrevemos a ninfa de A. ofaye Froehlich e um aparato para criação deste gênero. Este é o primeiro registro de A. ofaye no Estado do Paraná, Brasil.

Palavras chave: Plecoptera, Anacroneuria, ninfa, aparato de criação, Brasil

\section{Introduction}

Anacroneuria Klapálek 1909 (Plecoptera: Perlidae) is represented by more than 300 recognized species (Stark et al. 2009; DeWalt et al. 2010; Froehlich 2010; Righi-Cavallaro \& Lecci 2010; Stark et al. 2012) distributed throughout the Neotropics into the southwestern United States (Stark \& Kondratieff 2004; Stark et al. 2009). Considerable progress in the taxonomic knowledge of the genus has been achieved in recent decades (Stark 1995, 1998, 1999, 2001a, 2001b; Stark et al. 1999, 2001; Stark \& Sivec 1998; Zúñiga \& Stark 2002; Ribeiro-Ferreira \& Froehlich 2001; Froehlich 2002, 2007), both in descriptions of new species and in redescriptions of older species (Bispo \& Froehlich 2004). About seventy species of Anacroneuria are known from Brazil (Froehlich 2010); the nymphs of only two have been described (Righi-Cavallaro \& Lecci 2010; Avelino-Capistrano et al. 2011a). 